\title{
Articles
}

\section{A System for Analyzing Conversation Textbooks}

\author{
Takashi Miura \\ Shizuoka University
}

This paper proposes an aural/oral communicative English textbook analysis system that reveals the language learning theories behind the textbook and identifies the classroom procedures required to use it effectively. To promote systematic analysis I have created a set of scales that measures five major variables determining the characteristics of each text: (a) topic consistency; (b) type of syllabus; (c) frequency of drill use; (d) presence or absence of activities allowing the expression of the students' own ideas; and (e) types of language activities. These variables were generated by analysis of sixteen government-authorized textbooks published in 1995 for Oral Communication A, a new course aimed at developing Japanese senior high school students' ability to converse in English.

本論文は、口頭英語コミュニケーション教材の新しい分析システムを提案し、以って各 教科書が依拠する言語理論と学習理論を追跡し、各教科書が教室に創出する授業展開の予 測を可能ならしめることを目的としている。本研究では各教科書の特徴を決定づける主要 因として、(a) トピックの一貫性、(b) シラバスのタイプ、(c) ドリルの使用頻度、(d) 生徒が 自分の考えを述べる活動の有無、(e) 言語活動の夕イプ、の五つをとりあげ、各教科書にお けるこれらの変数を数量的に測定する尺度を提案している。これらの五つの主要因は、新 学習指導要領で開設された高校用オーラル・コミュニケーションA用に1995年に出版された 16 冊の検定教科書の分析の結果得られたものである。

I n this paper I will present a systematic method for analyzing English conversation textbooks. The method was developed to analyze the course books used for Aural/Oral Communication A (OC-A), a new senior high school English core course started in 1995. The course is aimed at developing conversational English ability in the Japanese English as a Foreign Language (EFL) high school instructional setting, where word-to-word translation and grammatical explanation of written text have played a dominant role for over a century.

With the advent of the new Monbusho Course of Study (Monbusho, 1989) announced by the Ministry of Education in 1988 and initiated in April 1994, textbook writers have been obliged to start promoting aural/ 
oral communication skills. The result has been publication of various kinds of textbooks claiming to contribute to the development of aural/ oral communicative ability. This kind of diversity is not only limited to OC-A textbooks, but is common to all textbooks for teaching English skills (for example, see Fortune's 1998 analysis of six EFL grammar texts). Regarding oral skills, Richards (1990) talks about the complexity of teaching conversation classes where the content and activities of textbooks vary from low-intervention communication tasks and games to highly structured teacher-fronted tasks or from free conversation to structured situational dialogues.

Because of this variability, it is important for teachers to select a textbook that suits their beliefs about the nature of language and language learning and engenders the kind of language activities they desire. Of course, at the same time teachers should continually explore these beliefs in the light of classroom outcomes and the latest developments in the fields of language acquisition and language teaching methodology.

\section{Developing a Textbook Analysis System}

The study presented here is based on a 1995 to 1997 analysis of sixteen Japanese government-authorized OC-A textbooks published in 1995. The textbooks were revised in April 1998 so this analysis is based on the pre-revision versions. However, the analysis system is independent of the books analyzed and is therefore applicable to a wide range of textbooks with similar components: model conversations, listening practice, comprehension questions, key expressions, language drills, language activities, and tasks.

\section{Analysis versus Evaluation}

In this paper I have avoided the term "evaluation," using "analysis" instead, since the former term often implies value judgments on the part of the evaluators. Rather, I propose a neutral analysis system composed of a set of scales, each representing a different analysis criterion. Such a system will promote a more objective assessment of textbooks and the data obtained will provide common ground for discussion regardless of teachers' preferences for various approaches and methods.

When creating an analysis system, it is not sufficient to merely propose a set of criteria for analysis, since the criteria themselves are not free of subjective assessment. In order to make them mutually compatible it is necessary to create a common numerical scale. Once such a scale has been established, it enables a quick review of the characteristics of the textbooks (see Appendix). Another advantage is that the analysis system 
can be used on any textbook or different versions of the same textbook, a significant point considering the frequent revisions of government-authorized textbooks in Japan. A third advantage is that by changing the content of the scales, the system can be converted into an analysis system for other types of textbooks, such as those used for writing.

\section{Research Focus}

What characteristics do the sixteen 1995 OC-A textbooks listed below (Table 1) share? Where are they different? These were the initial questions I considered. I read through the units of the textbooks and identified a number of similarities and differences, discussed below.

Table 1: The Sixteen Oral Communication-A Textbooks Surveyed

Active English Communication A (Ogawa et al., 1995)

Birdland Oral Communication A (Yoshida et al., 1995)

Echo English Course Oral Communication A (Yamamoto et al,, 1995)

English Street Oral Communication A (Hazumi et al., 1995)

Evergreen Communication A (Sasaki et al., 1995)

Expressways Oral Communication A (Suzuki et al., 1995)

Hello, There! Oral Communication A (Jimbo et al., 1995)

Laurel Oral Communication A (Tanabe et al., 1995)

Lighthouse Conversation (Takebayashi et al., 1995)

Mainstream Oral Communication A (Ando et al., 1995)

New Start English Communication A (Hanamoto et al., 1995)

Oral Communication Course A Interact (Ishii et al., 1995)

Sailing Oral Communication A (Toyoda et al., 1995)

Select Oral Communication A (Kitade et al., 1995)

Speak to the World Oral Communication A (Bowers et al., 1995)

The New Age Dialog (Araki et al., 1995)

Note: Only the first author is listed since some books have many authors. See the references for all of the authors' names.

\section{Similarities}

There were only a few similarities. All textbooks had a similar format for each unit consisting of about 8 to 15 lines of a model conversation accompanied by listening practice, comprehension questions, key expressions, language drills, language activities, and tasks. None of the textbooks contained authentic material, but there were a few textbooks aimed at generating authentic classroom use of the target language. 


\section{Differences}

The textbooks were different in the following areas:

1. Topic consistency;

2. Types of syllabuses;

3. Frequency of the use of drills;

4. Presence or absence of activities allowing students to produce language expressing their own ideas;

5. Types of language activities: (A) interactive or non-interactive; (B) creative or non-creative.

These five areas were used as the basis of my analysis and in the following sections I will describe these areas and propose practical measurement scales for analyzing them.

\section{Results and Discussion}

The results of the textbook analysis are summarized in the Appendix. This section will discuss the different scales, using examples from the textbooks to show their application.

\section{Scale 1: Topic Consistency-Topic Inconsistency}

One prominent difference in the textbooks was how topics were treated, specifically, whether a textbook had topic consistency or topic inconsistency in its units. Topic consistency means that the same topic is used throughout the textbook unit or chapter. A topic-consistent unit tends to emphasize content and the exchange of ideas; it provides students with a set of key words, expressions, and concepts related to a given topic to stimulate and promote students' communication in the target language. What follows is an example of a topic-consistent unit in an OC-A textbook. Here the topic of "sport" is used in all of the unit components:

From Hello, There! Oral Communication A (Jimbo et al., 1995, Unit 6 , pp. 42-45):

Unit title: My Favorite Sport.

Part 1 (1) Model dialogue 1 (12 lines about TV sport broadcasting) with tape-recorded comprehension questions

(2) Guided conversations (students' favorite spectator sports and their opinions about different sports)

Part 2 Model dialogue 2 (inviting friends to go skiing) with taperecorded comprehension questions 
Part 3 Task A: Interviewing peers using the following questions:

1. What kind of sports do you like?

2. Do you play it or do you just enjoy watching it?

3. Are you good at it? / Who's your favorite player?

Task B: Reporting the results of interviews to the class

Example: "Kumi likes soccer. She doesn't play it. She just

enjoys watching it on TV. Her favorite, soccer player is Kazu Miura."

In a topic-inconsistent unit, the topics may vary from one activity to another in the same unit, vary from one utterance to another even in the same exercise, or a topic as such is not identifiable. In a topic-inconsistent unit the emphasis is not on the content but on a particular language form or function. The instructional goal is to give students focused practice and/or drilling of the target language structure. Below is an example of a topic-inconsistent unit.

From Laurel Communication A (Tanabe et al., 1995, Unit 9, pp. 44-46):

Unit title: I'm Sorry I'm Late.

(1) A model dialogue on the topic of "appointment," with Japanese translation

(2) Key expressions: "I'm sorry I'm late." "That's all right." "Excuse me."

(3) Presentation of conversation gambits: I'm sorry/No problem; I'm sorry/Don't worry about it.

(4) Exercise A: Complete apologies, filling phrases from the attached list into the parentheses.

1. I'm sorry (I broke your window).

2. I'm sorry (I didn't finish the work).

3. I'm sorry (I forgot to buy the magazine).

4. I'm sorry (I didn't cook your egg right).

(5) Exercise B: 'Say, 'Excuse me,' and then explain why you must leave, using phrases from the attached list in parentheses."

1. Excuse me. I (have to see someone).

2. Excuse me. I (want to use the bathroom).

3. Excuse me. I (have to get back to my work).

4. Excuse me. I (want to make a phone call).

Here the topic shifts from appointments to baseball, jobs, books, cooking, biological needs, and telephoning. Sometimes a topic is unidentifiable; the focus of the unit is not a topic but use of "I'm sorry" and "Excuse me." 


\section{Scale 2: Syllabus Organization}

A second difference is syllabus organization. "Syllabus" refers to the principle of choosing and ordering the textbook content. Richards, Platt, and Platt (1992) explain that by identifying the type of syllabus used it is possible to understand the focus and contents of a course and whether the course will be structural (emphasizing grammar and vocabulary), situational (emphasizing language needed in various situations), or notional (emphasizing communicative functions). Although these researchers describe a course syllabus, their definition is applicable to the study of a textbook syllabus as well. The procedure used here for analyzing the syllabus of each textbook is as follows:

1. Analyze the basis of the organization of each unit. Is it a structure, a function, a topic, a situation, a skill, or something else?

2. Determine whether the same pattern of organization is used throughout the units in the textbook. If so, then this organization represents the syllabus. If some of the units are organized according to a certain principle (structural, for example), but the others are organized according to another principle (functional, for example), the textbook is considered to have a mixed syllabus.

3. Determine whether the textbook has a subordinate principle or sub-syllabus. A textbook written according to the principles of a certain type of syllabus may also have a sub-syllabus or a different type of organization for some parts of the unit. For example, in a textbook with a topical syllabus, part of each unit may be devoted to presenting language functions.

Nunan (1991) notes that, "beliefs on the nature of learning can also be inferred from an examination of teaching materials" (p. 210). The OC-A textbooks published in 1995 are written according to one or two of the following four types of textbook syllabuses: functional, topical, structural, and/or situational (see Appendix). The next section examines features of each syllabus type.

\section{Structural Syllabuses}

In a structural syllabus the textbook contents are arranged according to the structural components of the language, reflecting the following structuralist view of language:

Learning a language ... entails mastering the elements or building blocks of the language and learning the rules by which these elements are combined, from phoneme to morpheme to word to phrase to sentence (Richards \& Rodgers, 1986, p.49). 
The example below shows the first five units of an OC-A textbook with a structural syllabus. Although the unit titles do not include any structural metalanguage, the emphasis on structure is clear from the type of exercises included.

From Birdland Oral Communication A (Yoshida et al., 1995, pp. 8-17):

Unit Titles

1. In the Morning

2. The Last Two Tickets

3. Rain or Shine

4. Going to School

5. Going out to Dinner
Exercise Types

(conversion) I open the door. (He) $\mathrm{He}$ is opening the door.

(substitution) Thank you for___ing. (rejoinder) I think so, too. / I don't think so.

(conversion) I wait for the bus. (She) She is waiting for the bus.

(rejoinder) Really? I don't believe it. / That sounds great.

There are seven OC-A textbooks with structural syllabuses, one with a structural main syllabus, and six with structural sub-syllabuses (see Appendix).

\section{Functional Syllabuses}

In a functional syllabus, also called a notional-functional syllabus, the textbook content is arranged according to the purposes for which the language is used. It reflects the view that "language is a vehicle for the expression of functional meaning" (Richards \& Rodgers, 1986, p. 17). There are six OC-A textbooks with functional main syllabuses and eight with functional sub-syllabuses (see Appendix). A typical example is Evergreen Communication A (Sasaki et al., 1995); here the units are arranged according to functions such as "greeting," "requesting," "inviting," and "accepting."

\section{Topical Syllabuses}

A topical syllabus is one in which each unit concentrates on a particular topic such as "school life," "hobbies," or "health," and the content is arranged according to a series of topic headings. In the EFL situation in Japan, where there is little need for students to speak English outside the classroom, choosing appropriate topics is essential for enhancing students' motivation to participate in class.

None of the sixteen OC-A textbooks are written exclusively according to a topical syllabus. However, there are nine that partly employ topical 
syllabuses (see Appendix). For example, in Active English Communication A (Ogawa et al., 1995), eleven out of sixteen units are written according to a topical syllabus, with topics such as "school life," "family and relatives," "eating out," and "shopping."

\section{Situational Syllabuses}

A situational syllabus is one in which the textbook content is organized according to situations in which certain language is used, such as "at the airport," "at the doctor's office," and "in the classroom." There is one OC-A textbook written mainly according to this syllabus type and another with a situational sub-syllabus (see Appendix). In Expressways Oral Communication A (Suzuki et al., 1995), for example, the first ten units are written according to a situational syllabus consisting of situations such as "at the immigration office," "taking a taxi," "at dinner," "at a home-stay," and "at a bank."

Scale 3: The Use of Drills

\section{Defining Drills}

The third difference among the various OC-A textbooks surveyed is the use of drills. Here "drill" refers to language practice exercises such as "repetition, substitution, and transformation drills" (Richards, Platt, \& Platt, 1992, p. 117) in which students are required to produce utterances that contain target language elements for the purpose of "mastering the elements" (Richards and Rodgers, 1986, p. 49) rather than "using language for meaningful communication" (Richards \& Rodgers, 1986, p. 131). Some textbooks make extensive use of substitution drills and transformation drills, as in the following example.

From Birdland Oral Communication A (Yoshida et al., 1995, Unit 10, pp. 8-17)

Exercise A: "Convert these sentences, following the example."

(e.g.) I do the exercise. (He) He will do the exercise.

1. I ask my teacher a question. (She)

2. I look up a word in the dictionary. (My sister)

3. I take notes. (Tom)

4. I read my textbook. (They)

Here students are asked to produce utterances not for the purpose of conveying meaning but to master the "future auxiliary 'will' plus rootform verb" and the use of personal pronouns. 


\section{Theory Bebind Drills}

Richards and Rodgers (1986) note that extensive use of drills is a feature of audiolingualism reflecting structural linguistic theory and behaviorist psychology. It is possible to determine whether a textbook is based on structural and behaviorist beliefs by counting the number of drills used in each unit. This procedure enables us to penetrate the surface organization of a textbook, for even among textbooks with functional or topical syllabuses there are some exercises consisting of audiolingual drills, as in the previous example of the unit entitled "I'm Sorry I'm Late."

The calculation of drill frequency is done by selecting a typical unit and calculating the percentage of activities and/or exercises which belongs to the category of "drills," as defined above.

\section{Scale 4: Activities for Students to Express Their Own Ideas}

The fourth scale addresses activities that allow students to express their own ideas. The opposite of drills, such self-expression activities focus on meaning rather than on form and allow the student to generate their own language. The need to include activities for self-expression in OC-A textbooks is emphasized in the Monbusho's Course of Study (Monbusho, 1989) for OC-A, since this activity type is considered effective for enhancing students' motivation to participate in classroom activities. McDonough and Shaw (1993, cited in Edwards, Shortall, Willis, Quinn \& Leek, 1994) stress the importance of such materials to involve learners in meaningful talk to enhance learning.

\section{Features of Self-Expression Activities}

Letting students express their own ideas in the target language in a Japanese EFL classroom is no easy task. I have previously suggested (Miura, 1991) that preliminary activities must be used to provide essential background for the students before they attempt self-expression activities. Such precommunicative activities provide students with the motivation, ideas, lexical items, and discourse models that will culminate in successful self-expression.

Though many of the OC-A textbooks contain seemingly self-expression activities, they lack preliminary activities to provide the students with the necessary information and language items to facilitate their conversation. In the unit below, for example, the "Communicative Activity" at the end of the unit is completely isolated from the preceding activities in terms of both language and content: 
From The New Age Dialog (Araki et al., 1995, Unit 11, pp. 44-47):

Unit title: Beth Looks Back on the Summer.

(1) Model dialog on summer vacation and comprehension questions;

(2) Rejoinder drills on traveling;

(3) Guided conversation on summer vacation;

(4) Dialog completion drills on a high school baseball tournament;

(5) Communicative Activity: "Form two groups in the class, one favoring baseball and the other favoring soccer, and discuss why these two sports are fun."

In this example, the students are abruptly required to explain their preference for baseball or soccer without having been provided with enough information to discuss the sports, necessary lexical items to use, or discourse models to follow. Such isolated tasks do not seem to lead to self-expression in the ordinary EFL classroom in Japan and therefore cannot be counted as self-expression activities. Rather, I suggest that successful self-expression activities are:

1. Activities that motivate students to express themselves in short speeches or conversation on topics related to themselves;

2. Activities that accept and encourage original answers or utterances;

3. Activities that are preceded by sufficient models and accompanied by sufficient linguistic aids to allow students to accomplish the task successfully.

While discussing Scale 1, I introduced the unit "My Favorite Sport" as an example of a well-constructed self-expression activity in which simpler activities, activities (1) to (6), have been carefully organized to help students express their own views in the final two activities.

Self-expression activities tend to require lengthy preparation, so it is rare to find more than one such activity in each unit. I have counted the total number of self-expression activities in each textbook and found that there are only five books that contain one self-expression activity in each unit, six contain them in only some units and the remaining five books contain no activity of this type (see Appendix).

\section{Scale 5: Interactive and Creative Activities}

The final measure of differences among the 16 textbooks deals with the interactive, creative nature of the activities used. These concepts are operationalized as described below.

1. Interactiveness: Activities are interactive if it is necessary for the students to participate in conversational exchanges in the target language with their speech partners; 
2. Creativeness: Activities are creative if they allow students to create meaning and language for themselves instead of merely repeating predetermined utterances (e.g., substitution drills).

\section{Interactive/Noninteractive Activities}

As mentioned, interactive activities require a conversational exchange between students whereas noninteractive activities can be performed alone, without an interlocutor. Below is an example of a noninteractive activity.

From English Street Oral Communication A (Hazumi et al., 1995, Unit 7, p. 32):

Activity 2: "Perform a dialogue practice according to the example, substituting the underlined parts with the phone numbers in 1-4."

[example] A: Hello. May I speak to Kate?

B: I think you have the wrong number. What number are you calling?

A: 221-7313.

B: This is $211-7313$.

A: Oh, I'm sorry.

1. $2-8988 / 2-8998$

2. $38-3563 / 38-3536$

3. $872-0130 / 872-0930$

4. 3527-6938/3257-6938

It is doubtful whether this activity will promote meaning-focused interaction because the students do not have any reason to interact. In addition, this activity can be performed alone since the necessary information is already present. In such activities the existence of an interlocutor is unnecessary; therefore they are categorized as noninteractive. In this respect, Breen and Candlin (1987) suggest that materials for classroom work should have different features from materials that focus on individual language learning to encourage mutual language discovery among learners.

Let us compare the example above with Tasks A and B in Hello, There! (Jimbo et al., 1995, p. 45) discussed earlier. In Tasks A and B the students ask their classmates about their favorite sports to obtain the required information and report it to the class. Here the presence of interlocutors is necessary to perform the activity.

By employing the interactive/noninteractive distinction it is possible to identify the approach that underlies an activity. "Activity 2" in English Street (Hazumi et al., 1995) reflects behaviorist habit-formation theory in which "learners play a reactive role by responding to stimuli" (Richards 
\& Rodgers, 1986, p. 56). On the other hand, Tasks A and B reflect communicative theory in which "language learning comes about through using language communicatively, rather than through practicing language skills" (Richards \& Rodgers, 1986, p. 71). It should be noted that the Monbusho's (1989) Course of Study for OC-A puts a special emphasis on interactiveness, stressing development of the ability to talk with others (italics mine) about familiar matters, using expressions appropriate to the given situation and purpose" (pp. 32-34).

\section{Creative Activities}

The textbook survey shows that OC-A textbooks have different approaches to the creativity of activities. Some textbooks contain numerous activities that allow students' creative utterances (indicated as "creative" in the Appendix), while others contain activities that only accept predetermined utterances (indicated as "non-creative"). An example of a creative activity has already been given: Tasks A and B in Hello There! (Jimbo et al., 1995, p. 45). These tasks have a number of features which have been identified as likely to stimulate second language acquisition processes in the classroom (discussed in Ellis, 1994), and will most likely result in the following positive learning outcomes:

1. Students will be motivated to learn the interview questions by heart for the purpose of actually using them to obtain meaningful information from their classmates (Tasks A and B).

2. There is no predetermined answer provided so students are required to practice hypothesis testing (Brown, 1987, p. 168) in order to create their own utterances (Tasks $\mathrm{A}$ and $\mathrm{B}$ ).

3. Interviewers will have to listen to interviewees carefully because they cannot predict what the latter will say (Tasks A and B) and the responses must be written down.

4. Interviewers and interviewees will be obliged to negotiate meaning in order to understand the novel utterances created by their speech partners (Tasks A and B).

5. Students will "get to know each other personally" (Krashen \& Terrell, 1983, p. 73) through the exchange of personal information (Task B).

6. Students will listen to their classmates report about each other and further get to know each other (Tasks A and B).

7. Students' performances will be evaluated according to multiple criteria such as the quality of content and the correctness of form (Tasks A and B). 
When developing creative activities, "unpredictability" and "negotiation of meaning" (Edwards et al., 1994, p. 103) constitute important requirements for tasks for spoken communication. Without a certain degree of unpredictability, communication does not take place. Nunan (1991) emphasizes that "if language were totally predictable, communication would be unnecessary (i.e. if I know in advance exactly what you are going to say, then there is no point in my listening to you)" (p. 42). Also, hypothesis testing is considered to be important in communicative language acquisition theories (see Ellis, 1994). Those teachers who emphasize meaning over form will place more importance on unpredictability, negotiation of meaning, and hypothesis testing in their classrooms than those who emphasize form over meaning.

\section{Noncreative Activities}

At the other end of the creative/noncreative scale are activities that give no provision for students to produce their own utterances, as shown in the example below.

From Laurel English Communication A (Tanabe et al., 1995, Unit 12, p. 60):

Activity A. "Work in pairs. One person should ask, "Can I ?". The other person should answer yes or no."

(1) use a calculator, (2) take this book home, (3) take pictures in this museum

Activity B. "This time practice saying, 'You're not supposed to ,' as in the example. Use the same questions as in Activity A." [Example]

A: Can I use a calculator?

B: No, you can't. You're not supposed to use a calculator.

These activities are mechanical substitution drills. Their purpose is to reinforce the target structure "Can I $\sim$ ?," and there is no connection between the utterances and students' real life.

What types of learning outcomes are noncreative activities likely to promote? The following outcomes seem probable:

1. Students will be required to produce the utterances correctly, for there is no other goal.

2. Students do not have to pay attention to what their partner says, because he/she knows beforehand what will be said. This means that there will be no hypothesis testing or negotiation of meaning involved. 
3. There will be only one criterion of evaluation for this activity, the correctness of form.

4. As a result, teachers who are not confident in their own EFL ability will be able to teach this activity.

5. The activities do not facilitate socialization or personal understanding among students.

These learning outcomes seem almost negative. However, in terms of manageability they have positive aspects for EFL teaching in Japan because the great majority of English teachers in Japanese secondary schools are nonnative English speakers, and some lack the confidence to use unstructured oral activities. Most of the 16 textbooks contain both creative and noncreative activities. This is understandable when we consider the general tendency for language activities to proceed "from controlled to free practice" (Hubbard, Jones, Thornton, \& Wheeler, 1983, p.187).

\section{A Two-Axis Scale}

To graphically represent the features of the activities discussed in the previous two sections, I propose a two-axis scale, as shown in Figure 1. The horizontal axis indicates the creative/non-creative distinction, and the vertical axis indicates the interactive/noninteractive distinction.

Figure 1: A Two Axis Scale for Analyzing Conversation Textbook Activity Type Balance

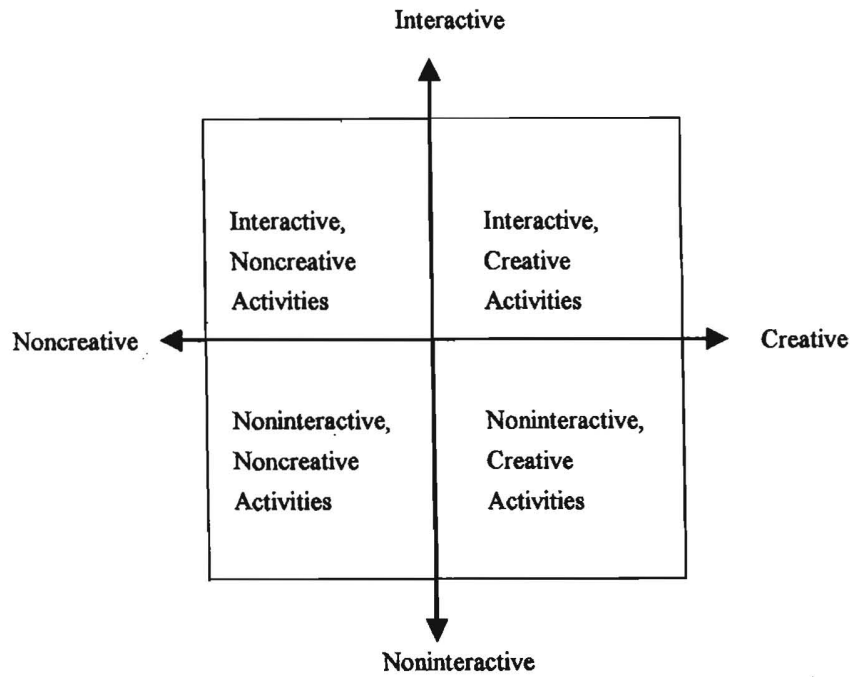


This gives four cells in the diagram:

1. Noninteractive, noncreative activities (the bottom left-hand cell in Figure 1):

This type of activity is not interactive and does not require creative utterances. Included in this type are repetition drills, substitution drills, transformation drills, and oral translation from the student's native language to English. The classroom relationship is basically between the teacher and isolated students, and the focus is on mastering a target language element. The following practice exercise is an example of a noninteractive substitution drill.

From New Start English Communication A (Hanamoto et al., 1995, Unit II-1, p. 21):

Let's Practice B: Substitute the underlined parts with the words provided below and practice the expressions.

Tell me about your school year.

1. ...... us ............... country.

2. ................. family.

3. .................. girlfriend.

2. Noninteractive, creative activities (the bottom right-hand cell in Figure 1):

This type of activity is not interactive, but allows creative utterances. Included in this type are guided oral composition and guided conversation. The activities may take the form of a dialogue, but a student does not necessarily need to interact with anyone else to complete the task. Below is an example of such an activity.

From Select Oral Communication A (Kitade et al.,1995, Unit 7, p. 45):

"Talk about your future dreams, filling proper words in the underlined parts."

What do you want to be in the future? - I want to be What country would you like to visit? - I'd like to visit If you had enough money, what would you like to buy? - I'd like to buy

3. Interactive, noncreative activities (the top left-hand cell in Figure 1): Included in this type are closed information gap activities that require oral interaction between two or more students but do not allow the students to use original utterances. Since they elicit only predetermined 
utterances, it is easy for both teachers and students to judge correctness. For example, Oral Communication Course A Interact (Ishii et al., 1995, pp. $8,44,60,84-86)$ uses three two-way information gap activities in which one student looks at a table of information and the other student looks at a different table, and they exchange information from their respective tables.

4. Interactive, creative activities (the top right-hand cell in Figure 1):

These activities require interaction between two or more students, and at the same time encourage students' original utterances. Included in this type are open information-gap activities and task-based activities. Below is an example of such an activity.

From Echo English Course Oral Communication A (Yamamoto et al., 1995, Unit 15, p. 57):

"You have received a letter from your friend in America. S/he is asking you for some tourist information about Japan. Ask these questions to several of your classmates, and record their answers in a table, following the example."

I want to visit Japan sometime next year.

Tell me:

What time of the year do you recommend to visit Japan?

What places do you recommend to visit?

What things do you recommend to see or do?

What do you recommend to buy for souvenirs?

Example:

\begin{tabular}{lllll} 
name & time & place & things to see/do & souvenirs \\
\hline Kiyomi & April & Kyoto & cherry blossoms & Kiyomizu-yaki \\
Makoto & May & Shizuoka & ride the Shinkansen & green tea
\end{tabular}

This activity requires student-student interaction. Although the interview questions are predetermined, there is no control over the form of the responses. Both the form and content of the responses depend on the interlocutor. In this type of activity, learning can occur through the target language exchange of personal opinions among the members of the classroom community.

\section{Combining the Scales}

I have proposed five scales for analyzing OC-A textbooks: (a) topic consistency; (b) syllabus types; (c) number of drills per unit; (d) number of activities for expressing students' own ideas; and (e) activity types (interactive and creative versus noninteractive and noncreative). Figure 
2 is an analysis chart of these five scales and their subcategories, accompanied by some guides for interpreting the figures in the table.

Figure 2: Aural/Oral Communication Textbook Analysis



Conclusion

Textbooks which appear similar often have different approaches, but it is usually only after we have started using a certain textbook that the mismatch between our beliefs and those of the textbook writers becomes clear. How can we avoid choosing the wrong textbook? It is this question that my study was intended to answer. I have used the proposed analysis system to examine the 16 OC-A textbooks published in 1995 and have obtained the following positive results regarding the ability of the system to analyze and compare various texts (see Appendix for details of the analysis):

1. The proposed analysis system enables teachers to categorize OC-A textbooks according to the criteria that they consider important for their classrooms.

2. The analysis system allows two or more scales to be combined. For example, the data on the analysis displayed in the Appendix is sorted primarily according to the percentage of creative and interactive activities and secondarily according to topic consistency versus topic inconsistency.

3. By displaying the textbook analysis data in a table, as shown in the Appendix, it is possible to compare textbooks quickly and easily.

4. By using the two-axis scale for "activity types," teachers can determine the response that a given textbook requires from both teachers and students. 
Of course it is time consuming to analyze textbooks in this way, but these results can be shared with other teachers. Such analysis does not tell teachers which textbook to choose, but gives them the data necessary to make their own decision.

\section{Acknowledgements}

A version of this paper bas appeared in The Bulletin of the Faculty of Education, Shizuoka University Educational Research Series 31, 1999 (published in March 2000).

Takashi Miura teaches at Shizuoka University. His major research interests are high school English education and teacher preparation.

\section{References}

Ando, S., Hale, D., Iseno, K., Okumura, K., Kawazumi, T., Komura, M., Chigusa, M., Harada, T., Hibino, H., Mizuno, M., Miyamoto, H., Yamamoto, R., \& Carmichael, E. M. (1995). Mainstream oral communication A. Osaka: Zoshindo. Araki, K., McCagg, P., Saito, S., Mikami, M., \& Yoshida, S. (1995). The new age dialog. Tokyo: Kenkyusha.

Bowers, J. R., Sakata, S., \& Murakami, M. (1995). Speak to the world oral communication $A$. Tokyo: Kyoiku Shuppan.

Breen, M., \& Candlin, C.N. (1987). Which materials? A consumer's and designer's guide. In L. Sheldon (Ed.), ELT textbooks and materials: Problems in evaluation and development. ELT Documents 126 (pp.13-28). London: Modern English Publications.

Brown, H. D. (1987). Principles of language learning and teaching. Englewood Cliffs, New Jersey: Prentice-Hall.

Edwards, C., Shortall, T., Willis, D., Quinn, A., \& Leek, P. (1994). Language teaching methodology. MA TES/FL, Open Learning Programme Coursebook, the University of Birmingham.

Ellis, R. (1994). The study of second language acquisition. Oxford: Oxford University Press.

Fortune, A. (1998). Survey review: Grammar practice books. ELT Journal, 52, 67-79.

Hanamoto, K., Ohi, K., Edamatsu, F. J., Kobayashi, A., \& O'Connor, W. F. (1995). New start English communication A. Tokyo: Obunsha.

Hazumi, E., Oda, Y., Kakei, T., Suzuki, H., Takeuchi, M., Tanaka, H., Tange, S., Matsunaga, T., \& Mutoh, N. (1995). English street oral communication A. Tokyo: Daiichi Gakushusha.

Hubbard, P., Jones, H., Thornton, B., \& Wheeler, R. (1983). A training course for TEFL. Oxford: Oxford University Press.

Ishii, B., Kishi, K., Naruge, N., Suzuki, F., Hasegawa, K., \& Phelan, T. J. (1995). Oral communication course A interact. Tokyo: Kirihara Shoten.

Jimbo, H., Ohmi, M., Okabe, R., Sakai, S., Tachibana, S., Nakamoto, T., Hisamura, K., Midorikawa, H., \& Peterson, L. M. (1995). Hello, there! Oral communication A. Tokyo: Tokyo Shoseki. 
Kitade, A., Mikami, M., \& Tanimoto, S. (1995). Select oral communication A. Tokyo: Sanseido.

Krashen, S., \& Terrell, T. (1983). The natural approach. Oxford: Pergamon Press. McDonough, J., \& Shaw, C. (1993). Materials and methods in ELT. Oxford: Blackwell.

Miura, T. (1991). Treating students' shyness and passivity. Aichi-ken eigo kyoiku kenkyuukai koutougakkou bukai kaishi, 30, 46-55. Aichi Prefectural Association of Senior High School English Teachers.

Monbusho. (1989). Koutougakkou shidouyouryou kaisetsu gaikokugo-ben eigoben [A guide to the course of study for upper-secondary school foreign languages]. Tokyo: Kyoiku-shuppan Co.

Nunan, D. (1991). Language teaching methodology. Hertfordshire: Prentice Hall.

Ogawa, K., Kuniyoshi, T., Akiyama, K., Imafuku, Y., Shimizu, M., Taneda, S., Tezuka, T., Yamaki, T., Allala, C. R., \& Okimoto, K. (1995). Active English communication A. Tokyo: Hitotsubashi Shuppan.

Richards, J. (1990). The language teaching matrix. Cambridge: CUP.

Richards, J., Platt, J., \& Platt, H. (1992). Longman dictionary of language teaching \& applied linguistics. Essex: Longman.

Richards, J., \& Rodgers, T. (1986). Approaches and methods in language teaching. Cambridge: CUP.

Sasaki, A., Ibarayama, Y., Yoshida, K., Watanabe, K., Minamimura, T., Ishihara, Y., Taniguchi, S., Nakai, M., Harada, R., Miura, T., Miyake, S., Watanabe, M., \& Babb, K. H. (1995). Evergreen communication A. Tokyo: Daiichi Gakushusha. Suzuki, S., West, W. W., West, D. K., Kobayashi, K., House, J. C., Mitsui, T., \& Yumoto, K. (1995). Expressways oral communication A. Tokyo: Kairyudo.

Takebayashi, S., Akasu, K., Katayama, M., Kurosaki, M., Shimizu, A., Yamada, N., Maki, S., Newell, A. P., Toyama, K., \& Roth, J. (1995). Lighthouse conversation. Tokyo: Kenkyusha.

Tanabe, Y., Matsuzaka, H., Aoyagi, F., \& Mahany, P. J. (1995). Laurel oral communication A. Tokyo: Sanseido.

Toyoda, M., Tanaka, S., Niwa, T., \& Mizuno, M. (1995). Sailing oral communication A. Osaka: Keirinkan.

Yamamoto, A., Zavislak, R. S., McDonald, K., Kashiwamura, M., Uehara, J., Kikuzumi, S., Kojima, M., Kobayashi, Y., Suzuki, K., \& Muroi, M. (1995). Echo English course oral communication A. Tokyo: Sanyusha.

Yoshida, K., Nissel, J. J., Barry, G., Ishikawa, K., Inoue, K., Sakagami, K., Soma, A., Tanabe, H., Yanase, K., \& Yamada, Y. (1995). Birdland oral communication A. Tokyo: Bun-eido. 
Appendix: Analygis of Textbook Treatment of Aural/Oral Communication

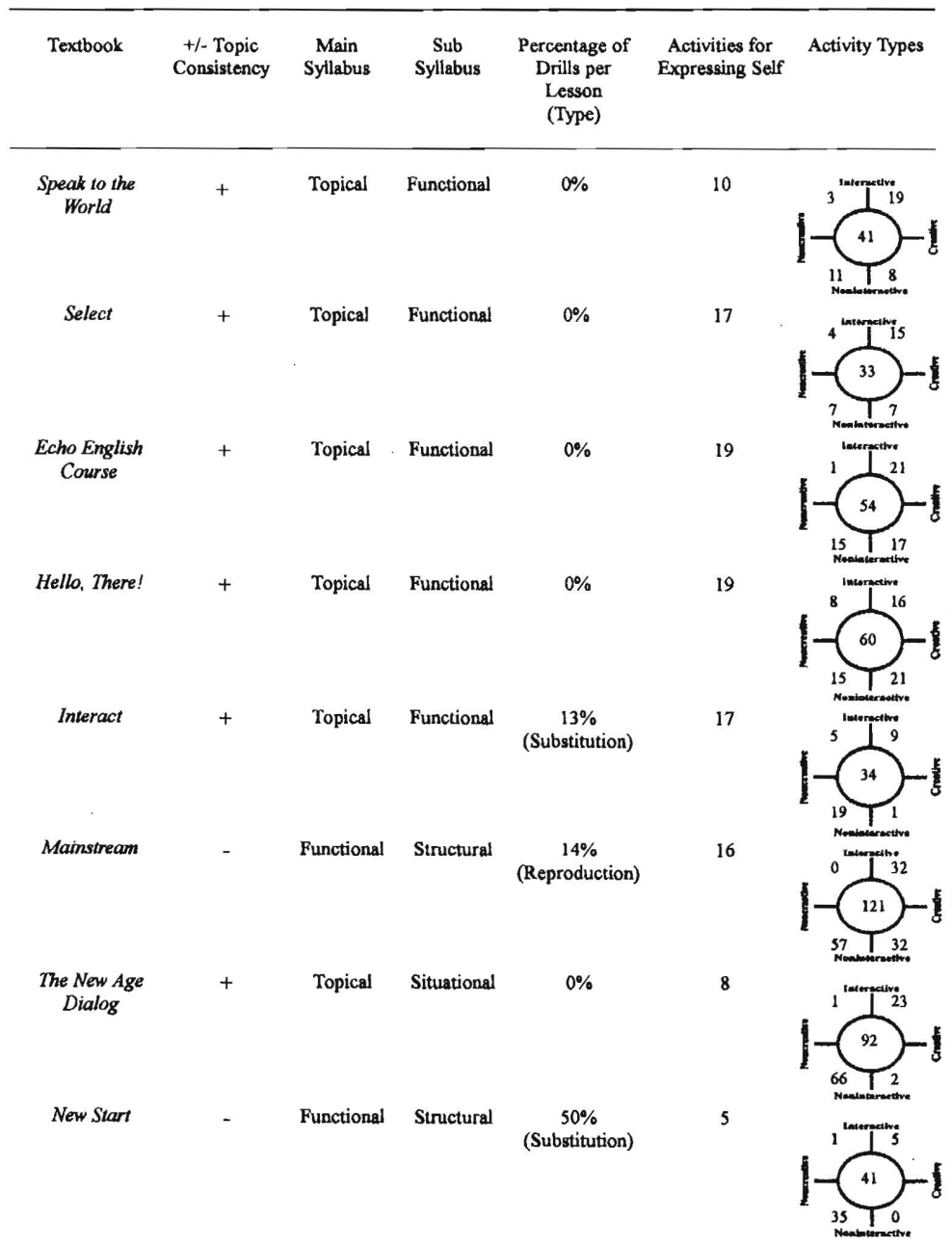




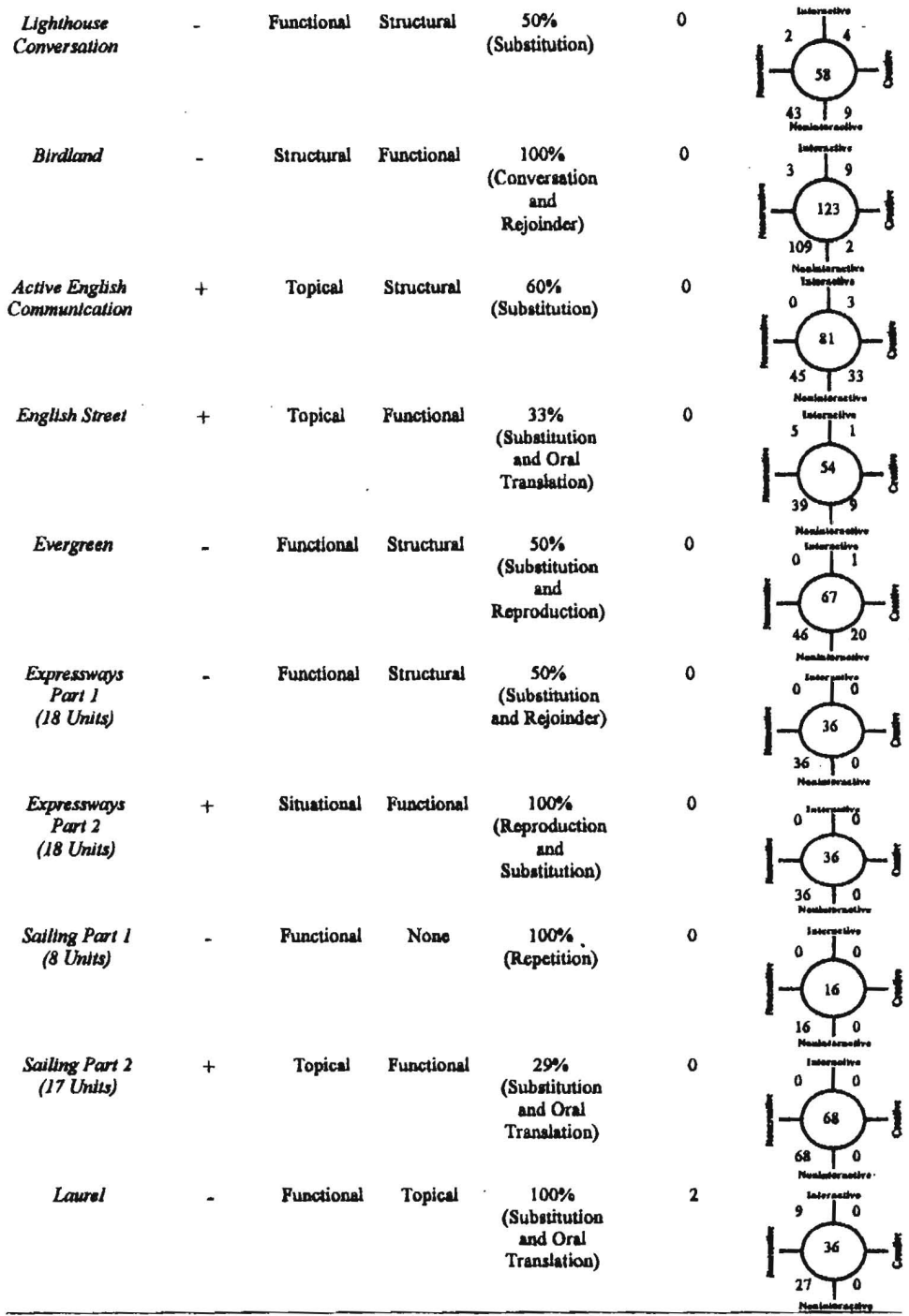

